\title{
MAKALAH
}

\section{PERSONEL KANTOR}

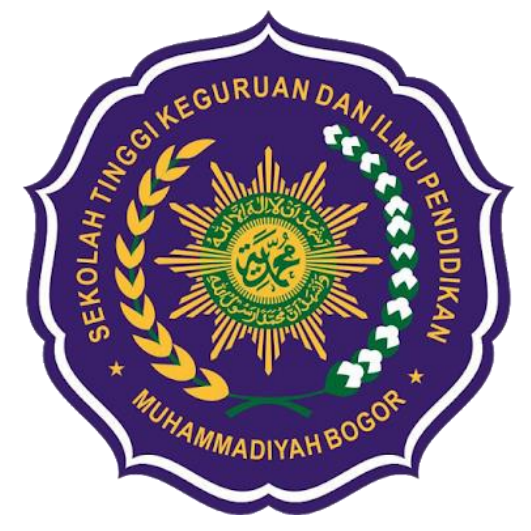

Dosen Pengampu : Resya Farkhrunnisa M.Pd

Mata Kuliah : Manajemen Kantor

Disusun Oleh

Dadang Darmawan

NIM 0142S1A018047 


\section{KATA PENGANTAR}

Alhamdulillah, puji syukur saya ucapkan kepada Allah SWT yang telah memberikan kepada hambanya berupa ilmu, yang alhamdulillah berkat ilmu itu saya dapat menyusun makalah ini.

Adapun tujuan dari penulisan ini adalah untuk memenuhi tugas mata kuliah Manajemen Kantor yang diampu oleh Dosen Ibu Resya Fakhrunnisa, M.Pd. sebagai Dosen dari Program Studi Administrasi Pendidikan. Adapun tugas yang saya kerjakan ini saya beri judul "Personel Kantor". selain itu, tujuan lainnya saya menulis ini adalah untuk menambah wawasan khususnya bagi saya sendiri dan umumnya bagi para pembaca.

Tak lupa saya ucapkan terima kasih kepada Orang tua saya yang selalu mendukung dan mendoakan saya dalam kegiatan apapun, kepada dosen yang sudah membimbing dan memberikan pengarahan dan tak lupa juga saya ucapkan terimakasih kepada teman-teman yang membantu menyelesaikan tugas ini.

Saya menyadari bahwa karya tulis ini masih jauh dari kata sempurna, oleh karena itu kritik dan saran akan saya terima guna untuk menjadi lebih baik lagi dimasa mendatang.

Bogor. Desember 2019

Dadang Darmawan 


\section{DAFTAR ISI}

KATA PENGANTAR ......................................................................... i

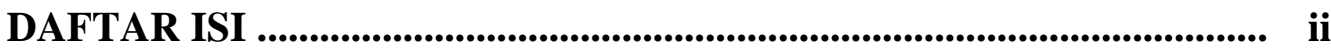

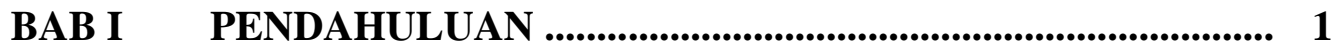

A. Latar Belakang ........................................................... 1

B. Rumusan Masalah ......................................................... $\quad \mathbf{1}$

C. Tujuan Masalah ............................................................. $\quad 2$

BAB II PEMBAHASAN _......................................................... 2

A. Pengertian Personel Kantor ................................................ 2

B. Macam-macam personel kantor ........................................ $\quad 2$

C. Tugas dan tanggungjawab personel kantor ......................... 3

D. Syarat-syarat personel kantor ............................................. 4

E. Tugas personel Kantor ................................................... $\quad 5$

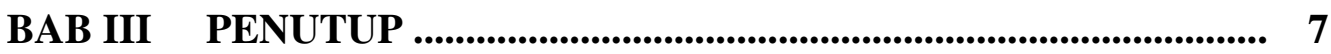

Kesimpulan ................................................................ $\quad 7$

Daftar Pustaka .................................................................. $\quad 8$ 


\section{BAB I}

\section{PENDAHULUAN}

\section{A. LATAR BELAKANG}

Organisasi sebagai kesatuan yang dinamis merupakan alat untuk mencapai tugas pokok. Bagaimanapun tegasnya tujuan yang digariskan, bila tidak didukung oleh ketetapan sasaran, baik yang berupa fasilitas maupun personal (pegawai) maka tetap saja tujuan tersebut tidak mempunyai arti apa-apa atau tidak bermakna.Tanpa unsur manusia sebagai personel maka tujuan organisasi yang telah ditentukan tidak akan tercapai sebagaimana yang diharapkan.

Kerjasama tidak akan terwujud, dan alat-alat merupakan benda mati serta waktu akan terbuang percuma. Jadi unsur manusia sebagai personel kantor merupakan unsur manajemen kantor yang sangat penting diperhatikan, karena tanpa adanya personel dalam kantor maka unsur yang lainnya tidak akan berarti apa-apa, dan sekalingus dikantor itu tidak akan ada kegiatan. Unsur personel dalam kantor merupakan salah satu komponen yang sangat penting dalam sebuah organisasi, oleh karena itu personel kantor harus memiliki bakat dan juga keahlian yang sesuai dengan keperluan kantor yang bersangkutan agar langkah untuk mencapai tujuan yang diinginkan oleh kantor tersebut dapat berjalan dengan lancar.

\section{B. RUMUSAN MASALAH}

1. apa yang dimaksud personel kantor?

2. Apakah macam-macam personel kantor?

3. Apakah tugas dan tanggungjawab personel kantor?

4. apakah syarat-syarat untuk menjadi personel kantor?

5. apa yang harus disiapkan personel kantor untuk melakukan tugasnya? 


\section{TUJUAN MASALAH}

1. Untuk mengetahui apa yang dimaksud personel kantor?

2. Untuk mengetahui macam-macam personel kantor?

3. Untuk Mengetahui tugas dan tanggungjawab personel kantor?

4. Untuk mengetahui syarat-syarat untuk menjadi personel kantor?

5. Untuk mengetahui apa yang harus disiapkan personel kantor untuk melakukan tugasnya?

\section{BAB II}

\section{PEMBAHASAN}

\section{A. Pengertian}

Kantor merupakan Tempat diselenggaraknnya proses penanganan informasi mulai dari menerima, mengumpulkan, mengolah, menyimpan, sampai menyalurkan informasi. Untuk lebih jelasnya Berikut adalah penjelasan singkat tentang pengertian perkantoran, macam-macam personil kantor, perangkat kerja personil kantor dan Syarat-syarat personil kantor.

Orang-orang yang menjalankan pekerjaan kantor disebut personel kantor. Sama seperti orang-orang lain dengan fungsi lain di organisasi yang sama, personel kantor merupakan aparat organisasi, yakni alat (dalam bahasa Latin aparatus berani 'alat') atau sumber daya untuk mencapai tujuan orgionsasi. Kekhususan personel kantor adalah bahwa ia mengelola informasi-informasi yang diperlukan bagi berjalannya keseluruhan organisasi.

\section{B. Macam-Macam Personel Kantor}

Ada empat macam Personel Kantor diantaranya :

Administrator (Kepala Administrasi) 
Orang-orang yang menentukan tujuan dan kebijaksanaan, memberikan garis-garis besar yang akan digunakan sebagai pedoman pokok dalam pelaksanaan kegiatankegiatan guna mencapai tujuan organisasi.

\section{Manajer (Pimpinan Pelaksana Kerja)}

Orang-orang yang memimpin penyelenggaraan kerja, menggerakkan orang lain, mendayagunakan uang, mesin, alat-alat dan sarana lainnya untuk mencapai tujuan organisasi yang telah ditetapkan.

\section{Staf (Pembantu Ahli)}

Mereka yang karena keahlian dan kecakapannya serta kemampuannya dalam bidang-bidang tertentu, bertugas membantu administrator dan manajer dalam kegiatannya untuk mencapai tujuan organisasi yang telah ditetapkan.

Worker (Pegawai atau Pekerja)

Mereka yang secara langsung digerakkan oleh manajer untuk bertindak sebagai pelaksana yang akan menyelenggarakan pekerjaan, sehingga menghasilkan karyakarya dalam usaha pencapaian tujuan organisasi.

\section{Tugas dan Tanggung Jawab Personel Kantor}

Jenis dan besarnya suatu organisasi sangat menentukan tugas dan tanggung jawab personel kantor yang bersangkutan. Dalam sebuah organisasi kecil bisa jadi seluruh pekerjaan kantor diserahkan kepada satu sekretaris saja, sehingga ia mengerjakan berbagai macam tugas mengetik surat, mengarsip surat, mencatat pemasukan dan pengeluaran, membuat laporan, membayar gaji karyawan, menerima tamu, dan sebagainya. Sebaliknya. dalam sebuah organisasi yang besar mungkin pekerjaan kantor dibagi-bagi ke dalam unit-unit tersendiri dengan tim personel masing-masing yang memiliki tugas dan tanggungjawab berbeda-beda pula. Namun, berdasarkan cakupan pekerjaan kantor yang umum. dapatlah disebutkan beberapa tugas dan tanggung jawab personel kantor sebagai berikut : 
a. Kepala kantor bertanggung jawab atas beresnya penyelenggaraan seluruh pekerjaan kantor. Tugasnya antara lain mengatur mekanisme kerja dan pembagian tugas di antar seluruh personel kantor mengawasi kebenaran, ketepatan, dan kerapian kerja para personel; mengurus pemenuhan perlengkapan kantor sesuai kebutuhan dansebagainya.

b. Petugas arsip bertanggung jawab atas pencatatan dan penyimpanan semua surat masuk dankeluar.

c. Pembuat surat bertanggung jawab atas pembuatan konsep surat keluar. d. Penerima tamu bertanggung jawab alas pelayanan terhadap tamu dan menerima telepon.

e. Petugas keuangan/kasir bertanggung jawab atas pengelolaan kas dan pembukuannya secara cermat.

\section{Syarat-Syarat Personal Kantor}

Setiap personel kantor perlu memenuhi syarat-syarat sesuai dengan bidang tugas dan pekerjaannya. Secara umum, syarat-syarat personel kantor adalah sebagai berikut.

a. Syarat Pengetahuan

Personel kantor harus dapat melakukan penggolongan/klasifikasi berdasarkan kriteria tertentu. la perlu menguasai matematika sederhana, tata bahasa Indonesia, dan sebaiknya pula bahasa lnggris secukupnya. Syarat pengetahuan ini antara lain dapat dijamin, meskipun tidak selalu, oleh bekal pendidikan yang telah dicapai oleh personel yang bersangkutan, misalnya SLTP, SMU, SMK, diploma. atau sarjana.

b. Syarat Keterampilan

Sekurang-kurangnya personel kantor harus dapat membaca dan menulis dengan cukup baik. Keterampilan dasar lain yang umumnya dituntut juga adalah mengetik. Dengan berkembangnya teknologi. kemampuan menggunakan aplikasi 
komputer juga semakin banyak dituntut, khususnya aplikasi pengolah kata dan pengolah data. Selain itu, personel kantor perlu memiliki kemampuan melaksanakan pekerjaan secara cermat, teliti, dan berhasil, sesuai dengan standar atau prosedur yang telah ditentukan dalam bidangnya.

c. Syarat Kepribadian

Kepribadian setiap orang tentu saja unik dan berbeda-beda. Akan tetapi, ada unsur-unsur sikap yang umum. yang idealnya dimiliki oleh personel kantor, yakni (1) loyalitas, yaitu kesetiaan terhadap organisasi dan pekerjaannya; (2) dapat menyimpan rahasia, terutama karena pekerjaannya banyak berkaitan dengan informasi-informasi penting dan rahasia perusahaan; (3) ketekunan dan kerajinan; (4) kerapian.

\section{E. Tugas Personel Kantor}

Agar personel kantor dapat menjalankan tugasnya dengan sebaik mungkin dan sesuai dengan tujuan yang hasil diharapkan, mereka perlu diberi perlengkapan kerja yang memadai, antara lain meja, lemari arsip, kursi, alat tulis, mesin tik, komputer, kop surat, formulir-formulir, korektor (tipp-ex), penjepit kertas, stapler, buku agenda, penggaris, dan sebagainya.

Sebaiknya juga disediakan berbagai pedoman untuk dijadikan rujukan pada saat personel kantor menjalankan tugasnya. Beberapa pedoman tugas personel kantor yang biasanya diperlukan adalah:

- Bagan organisasi;

- Tugas-tugas pekerjaan;

- Tugas-tugas kerumahtanggaan

- Tata cara menelepon;

- Tata cara pelayanan tamu;

- Contoh-contoh bentuk surat dan memo;

- Daftar penyimpanan semua berkas beserta letaknya;

- Daftar alamat dan nomor telepon karyawan dan relasi;

- Peraturan keamanan dari perusahaan; 
- Prosedur mengurus perjalanan dan penginapan di hotel:

- Jadwal rapat/pertemuan dan prosedur pengurusannya;

- Prosedur penulisan pengeluaran uang;

- Prosedur pemesanan perlengkapan barang;

- Pedoman tata bahasa dan penggunaan tanda baca.

Dengan perlengkapan yang memadai dan dengan berbagai pedoman yang praktis itu, personel kantor mengetahui persis apa yang harus dilakukannya dan bagaimana menjalankannya dengan cara sebaik mungkin. 


\section{BAB III}

\section{PENUTUP}

\section{KESIMPULAN}

Manjemen perkantoran merupakan kerjasama diantara sekelompok orang untuk mencapai tujuan kantor yang telaj ditetapkan sebelumnya dengan melaksanakan fungsi-fungsi manajemen perkantoran.

Untuk dapat menunjang efektifitas kerja pegawai/personal kantor maka diperlukan beberapa cara yaitu melalui beberapa ketentuan seperti syarat - syarat, melakukan beberapa seleksi, dan mengetahui beberapa tugas serta wewenang personal kantor.

Dengan melalui kesimpulan tersebut maka akan diperoleh hasil yang maksimal, baik serta memuaskan bagi manajemen perkantoran dan para pegawai/personal kantor didalam instansi pemerintah manapun. 


\section{DAFTAR PUSTAKA}

http://seputarpengertian.blogspot.com

http://ujiansma.com

http://rheiainud.blogspot.com

http://ratnawulandari12.blogspot.com

http://muhammadyusufstia.blogspot.com 